\title{
Mean and Seasonal Circulation of the South Indian Ocean Estimated by Combining Satellite Altimetry and Surface Drifter Observations
}

\author{
N. Peter Benny ${ }^{1, *}$, Daisuke Ambe ${ }^{2}$, K. Rayaroth Mridula ${ }^{1}$, Sahrum Ses $^{1}$, Kamaludin Mohd Omar $^{1}$, and \\ Mohd Razali Mahmud ${ }^{1}$ \\ ${ }^{1}$ University of Technology Malaysia, Johor, Malaysia \\ ${ }^{2}$ National Research Institute of Fisheries Sciences, Yokohama, Japan
}

Received 10 September 2012, accepted 5 August 2013

\begin{abstract}
The mean velocity field of south Indian Ocean has been derived by combining high resolution maps of sea level anomalies and the surface drifter data from the Global Drifter program from 1993 to 2012 with a resolution of $1 / 3 \times 1 / 3$ degrees in latitude and longitude. The estimated mean velocity field exhibits strong western boundary currents, zonal currents and eastern boundary currents. The Agulhas Current shows a velocity of above $1.5 \mathrm{~m} \mathrm{~s}^{-1}$ at around $35^{\circ} \mathrm{S}$. The distribution of energy associated with the fluctuating motion and the mean flow illustrates that mesoscale variability are particularly relevant in the Mozambique Channel, south of Java and around $40^{\circ} \mathrm{S}$. Advection of mesoscale features along the western boundary is evident in the distribution of eddy fluxes. The long-term average monthly surface velocity field exhibits large variations in surface currents. The most change is observed in the South Equatorial Current which shows spatial and temporal variations.
\end{abstract}

Key words: South Indian Ocean, Circulation, Currents, Satellite altimetry, Surface drifter

Citation: Benny, N. P., D. Ambe, K. R. Mridula, S. Ses, K. M. Omar, and M. R. Mahmud, 2014: Mean and seasonal circulation of the South Indian Ocean estimated by combining satellite altimetry and surface drifter observations. Terr. Atmos. Ocean. Sci., 25, 91-106, doi: 10.3319/TAO.2013.08.05.01(Oc)

\section{INTRODUCTION}

South Indian Ocean plays a major role in the global ocean circulation by mediating inter-oceanic exchanges between Pacific and Atlantic oceans. The tropical waters of the Pacific Ocean enter through the Indonesian Passage, feed into the South Equatorial Current and finally detrain to the South Atlantic Ocean through the western boundary Agulhas leakage.

Early systematic information on south Indian Ocean circulation was obtained from hydrographic observations during the International Indian Ocean Expedition (Wyrtki 1971). Later, studies conducted by Reverdin et al. (1983), Shetye and Michael (1988), Molinari et al. (1990) and Shenoi et al. (1999) enhanced our understanding. Kindle and Thomson (1989) and Woodberry et al. (1989) performed modelling studies to simulate the large-scale upper ocean circulation.

Further studies of Gründlingh et al. (1991), Stramma and Lutjeharms (1997), and Roshin et al. (2010) portrayed

\footnotetext{
* Corresponding author

E-mail: bennyneettumkara@utm.my
}

the upper ocean circulation of the southwest Indian Ocean. Benny and Mizuno (2000) derived the surface circulation of the tropical Indian Ocean from temperature profiles. Employing historical hydrographical observations, Reid (2003) gave a description of the Indian Ocean circulation. Palastanga et al. (2007) accounted the flow structure and variability of the subtropical south Indian Ocean, employing altimetry and model. The south eastern Indian Ocean circulation is noted in Qu and Meyers (2005) and Divakaran and Brassington (2011).

Moreover, global scale studies (Ducet et al. 2000; Niiler 2001; Rio and Hernandez 2004; Pascual et al. 2006; Sudre and Morrow 2008; Maximmenko et al. 2009; Rio et al. 2011) on the estimation of mean dynamic topography using satellite altimetry have also improved our understanding of south Indian Ocean dynamics.

As south Indian Ocean does not experience monsoon winds, the seasonal circulation is not as variable as in the north Indian Ocean. A schematic view of mean surface currents in the south Indian Ocean is given in Fig. 1. The South Equatorial Current in the Indian Ocean shows spatial and temporal variations due to the fluctuations in the Indonesian 


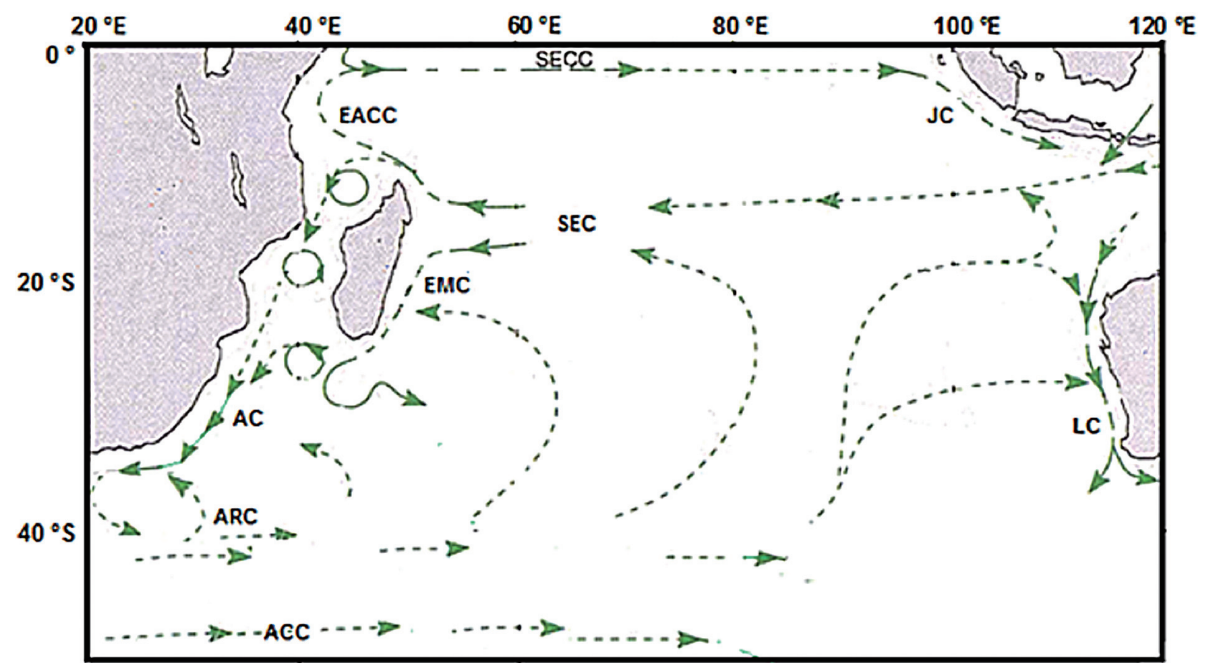

Fig. 1. Schematic view of the mean south Indian Ocean surface currents (modified from Schott and McCreary 2001). The different currents presented are the South Equatorial Current (SEC); East Madagascar Current (EMC); Agulhas Current (AC); Agulhas return Current (ARC); East Africa Coastal Current (EACC); South Equatorial Counter Current (SECC); South Java Current (JC); Leeuwin Current (LC) and Antarctic Circumpolar Current (ACC).

Throughflow and the changes in the wind filed (Matano et al. 2008). On approaching the northwest tip of Madagascar, the South Equatorial Current splits into two branches wherein one branch turns southward and flows as the East Madagascar Current. The other branch heads towards the African Coast, where it bifurcates again into northern and southern flows. The southward component flows through the Mozambique Channel; it does not proceed as a continuous western boundary current and instead break up into a train of eddies around the narrow section of the Channel (de Ruijter et al. 2002). Satellite observations show the inter-annual variability of the rate of the formation of Mozambique Channel eddies, probably related to the large scale climate anomalies over the Equatorial Indian Ocean (Schouten et al. 2002; Palastanga et al. 2006).

The East Madagascar Current flows along the eastern coast of Madagascar and when it reaches the southern tip of Madagascar, a major part of the current turns southwestward and joins the Mozambique Current to form the Agulhas Current, the strongest western boundary current in the Southern Hemisphere, with estimates of its transport as high as around $100 \mathrm{~Sv}$ (Jacobs and Georgi 1977; Gordon et al. 1987; Bennett 1988; Bryden and Beal 2001). From year-long current measurements of the Agulhas Current, the mean transport is obtained as $70 \mathrm{~Sv}$ (Beal and Bryden 1999). Modelling studies (Biastoch et al. 1999; Reason et al. 2003) suggest that seasonal anomaly in the tropical circulation propagates poleward through the Mozambique Channel and influences the mass transport of the Agulhas Current.

The Agulhas Current is primarily driven by the large scale pattern of wind stress curl between the southeast trade winds and the westerlies (Lutjeharms 2006). It flows along the east coast of Africa as a narrow fast boundary current until it is separated from the continent, looping anticlockwise south of Africa and feeding back into the Indian Ocean as the eastward Agulhas Return Current. This loop known as Agulhas Retroflection (Gordon 2003), sheds rings, eddies and filaments to the west, representing the leakage of Indo-Pacific waters into the Atlantic (Beal et al. 2011). The intense retroflection of the Agulhas Current distinguishes it from the subtropical western boundary currents of the other oceans (Gordon 1985; Lutjeharms 1996; Gordon et al. 1999). The return current is embedded with mesoscale eddies and a significant quantity of water is transported to the eastern part of south Indian Ocean along with the meandering flow.

In the eastern part of the south Indian Ocean, the coastal currents south of Java and the Leeuwin Current along the western coast of Australia also contribute significantly to the inter-basin exchanges. The South Java Current is an eastward flow with strong semi-annual and intra seasonal variability near the coast of Java and Sumatra (Qu and Meyers 2005). Eastward flow of the South Java Current is strong during May - June and October - November periods and the flow reverses westward in other seasons (Quadfasel and Cresswell 1992; Bray et al. 1996). The seasonal reversal of the current is attributed to several reasons like changing monsoon winds, fresh water flux as well as to the equatorial wave activity (Wijffels and Meyers 2004).

The Leeuwin Current in the south Indian Ocean is unique in that it is poleward and flows against the prevailing wind. The southward transport of warm water by the Leeuwin Current is confirmed from satellite tracked drifters (Cresswell and Golding 1980) and from satellite images (Pearce and Cresswell 1985). The Leeuwin Current is embedded with warm core eddies (Morrow et al. 2003) and the flow shows seasonal variations (Feng et al. 2003; Benny et al. 2005). 
As most of the previous studies were carried out on a regional basis mainly in the southeast and southwest sectors of the south Indian Ocean, a comprehensive view of the whole south Indian Ocean circulation is still lacking. Also, global scale studies are not discussing in detail the basin scale characteristics and variability. In the south Indian Ocean where there is no comprehensive in-situ observational system, altimeter data is one of the most important data streams for describing the ocean circulation. In addition, the large number of satellite tracking surface drifters deployed as a part of the Global Drifter Program also supplied in-situ data. Hence, in the present study, efforts have been made to present a high resolution $(1 / 3 \times 1 / 3$ degrees latitude and longitude) quantitative description of the mean circulation and seasonal variability of the south Indian Ocean currents by combining satellite altimeter and the satellite tracked drifter observations. The drifters provide more accurate, but sparser in-situ velocity observations and have been used to calibrate the satellite data. The satellite data is a more evenly sampled field over time and was used to compute the mean.

Mesoscale variability of ocean circulation is essential for understanding the interaction between ocean and atmosphere. In the present study, the Eddy Kinetic Energy (EKE), which is a measure of the degree of mesoscale variability, the Mean Kinetic Energy (MKE), ratio of EKE to MKE as well as the eddy fluxes have also been presented to infer the mesoscale variability occurring in south Indian Ocean.

\section{DATA AND METHODOLOGY}

The present study utilizes satellite altimetry, satellite tracked surface drifter data and ocean surface wind data from 1993 to 2012. The satellite altimeter data used in this study are delayed mode, Maps of Sea Level Anomaly (MSLA) produced by the Collect Localisation Satellites (CLS), France. The MSLA were obtained by merging JASON/TOPEX/POSEIDON and European Remote Sensing Satellites ERS/Envisat data using optimum interpolation (AVISO 1997). Maps were produced in intervals of every seven days since August 1992 with a resolution of $1 / 3^{\circ}$ in both latitude and longitude and referenced relative to the 1993 - 1999 mean time period.

The surface drifter data used in this study is from the Global Drifter Program (Surface Velocity Program), with the transient positions of freely drifting buoys located using the ARGOS satellite system. The surface buoys are attached to drogues centred at a depth of $15 \mathrm{~m}$. Data used are quality controlled and optimally interpolated to create uniform six-hour interval trajectories (Hansen and Poulain 1996) using the drifters' position data. This data set is compiled and maintained by the Drifter Data Centre at the Atlantic Oceanographic and Meteorological Laboratory of the National Oceanic and Atmospheric Administration, USA. The drifter tracks available for the study region during the period
1993 - 2012 (Fig. 2) show sparse coverage in the Indonesian Passage.

The weekly ocean surface mean wind fields $(0.5 \times 0.5$ degrees resolution) produced by the Centre ERS d'Archivage et de Traitement (French) (CERSAT) (http://cersat.ifremer. $\mathrm{fr} /)$ at the French Research Institute for Exploration of the Sea (IFREMER) have also been used to separate the winddriven component from the drifter velocity. The product is derived from the measurements with scatterometers on board the European Space Agency satellites on ERS 1/2, QuikSCAT and ASCAT.

The method introduced by Uchida and Imawaki (2003) has been employed in this study wherein surface drifter and altimeter data are combined to estimate the mean surface velocity. At a location $\mathrm{x}$ and time $\mathrm{t}$, the instantaneous geostrophic velocity.

$\operatorname{Vg}(\mathrm{x}, \mathrm{t})$ can be written as:

$\mathrm{Vg}(\mathrm{x}, \mathrm{t})=\operatorname{Vmg}(\mathrm{x})+\mathrm{Vg}^{\prime}(\mathrm{x}, \mathrm{t})$

Where, $\operatorname{Vmg}(\mathrm{x})$ is the mean geostrophic velocity, and $\mathrm{Vg}^{\prime}(\mathrm{x}, \mathrm{t})$ is the geostrophic velocity anomaly, i.e.,

$\operatorname{Vmg}(x)=\operatorname{Vg}(x, t)-\operatorname{Vg}^{\prime}(x, t)$

The instantaneous geostrophic velocity can be derived from the drifter observations whereas; the altimeter sea level anomalies provide the anomaly field. Hence, the mean velocity is calculated by subtracting the altimeter derived geostrophic velocity anomaly from the drifter-derived geostrophic velocity measured at the same time and location. This method estimates almost unbiased Eulerian mean velocities which are free from the sampling tendency of the drifters. Thus, the unknown mean velocity can be estimated for the grid box where a drifter passed. The average of the calculated mean velocities in each grid, $<\mathrm{Vmg}(\mathrm{x})>$ gives a more accurate estimate by reducing the estimation error.

To remove high frequency fluctuations, the drifter trajectories have been low-pass filtered by a 30 hour running mean. Then, the drifter data has been gridded into $1 / 3^{\circ} \times 1 / 3^{\circ}$ latitude $\times$ longitude boxes of altimeter observations. The surface velocity has been estimated from the drifter position data in each grid (Fig. 3). The wind-produced slip has been corrected employing the relation given by Niiler and Paduan (1995). An additional correction has been made for drifters which had lost its drogues during its traverse, using the empirical relation given by Pazan and Niiler (2001). The Ekman velocity has been estimated employing the Ralph and Niiler (1999) model. The geostrophic velocity component has been separated from the drifter velocity by subtracting the Ekman component.

The components of geostrophic velocity anomaly have been computed from altimeter sea level anomaly data using 
the conventional geostrophic relation.

$u^{\prime}=-\frac{g}{f} \frac{\partial h}{\partial y}$

$v^{\prime}=\frac{g}{f} \frac{\partial h}{\partial x}$

The time series maps of instantaneous geostrophic velocity field have been prepared by combining the time series MSLA with the estimated mean velocity field.
In this study, the MKE and EKE have been estimated from the components of mean velocity $\mathrm{Vmg}$ and velocity anomaly $\mathrm{Vg}$ ' respectively as:

$\operatorname{MKE}=1 / 2\left(u^{2}+v^{2}\right)$

$\mathrm{EKE}=1 / 2\left(u^{\prime 2}+v^{\prime 2}\right)$

This MKE and EKE estimation can only represent energy contained in mean and anomalous surface currents under

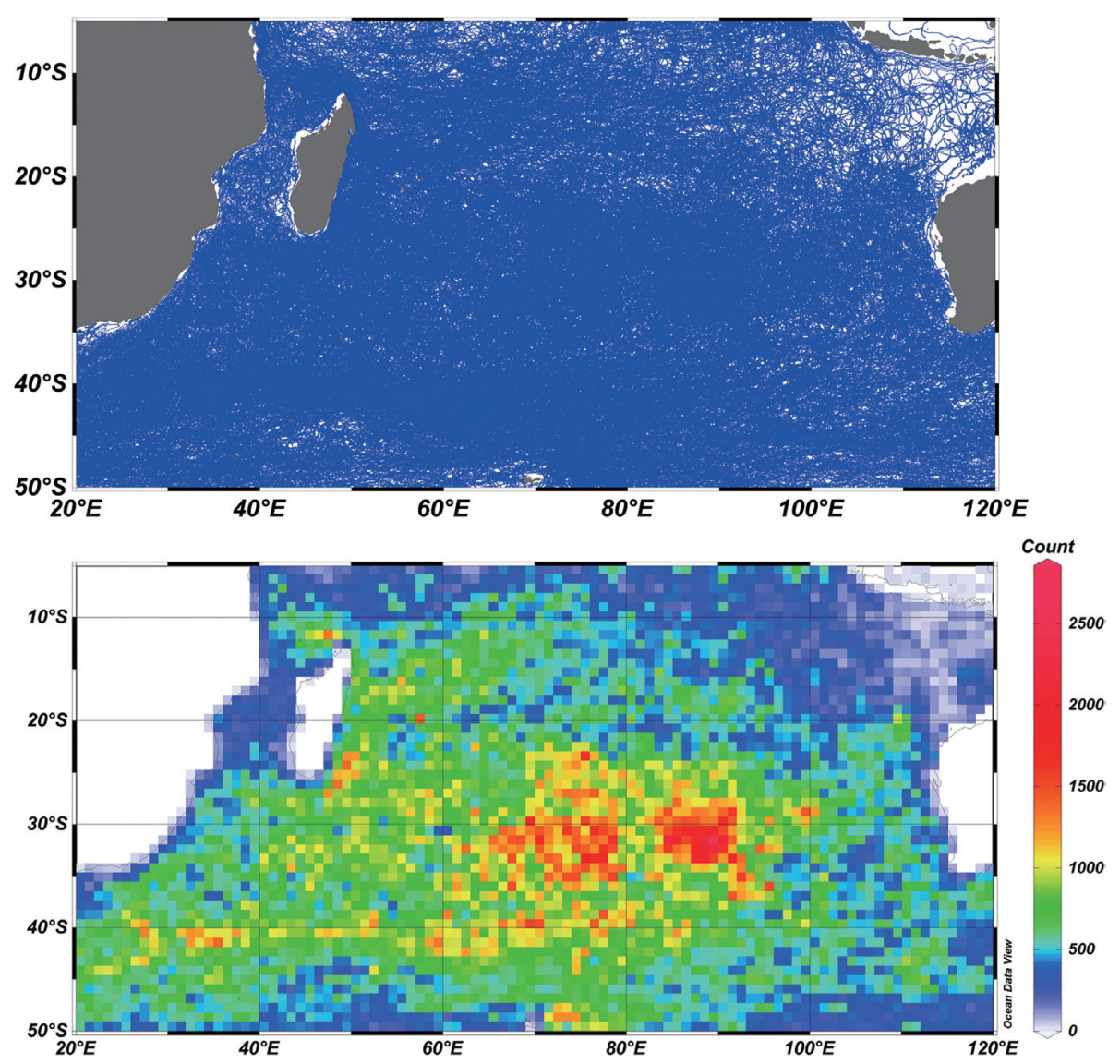

Fig. 2. Drifter tracks in the south Indian Ocean (1993 - 2012) and data statistics.

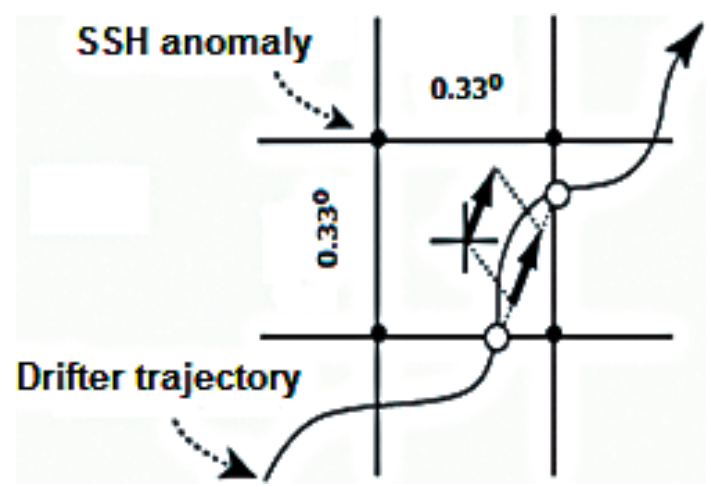

Fig. 3. Schematic diagram showing the method to calculate a velocity from a low pass-filtered drifter trajectory. The velocity for a $1 / 3 \times 1 / 3$ longitude box defined by grid points of the altimeter data is calculated from two positions (open circles) and times where and when a drifter comes in and goes out the box. 
the geostrophic approximation. Eddy fluxes have been computed by taking the temporal average of product of velocity anomalies $\left(\left\langle u^{\prime} v^{\prime}\right\rangle\right)$ (Emery and Thomson 2001).

\section{RESULTS AND DISCUSSION}

\subsection{Mean Velocity Field}

The Eulerian mean velocity field obtained by combining the satellite altimeter and drifter data reveals the near surface flow pattern of the south Indian Ocean (Fig. 4a, the gaps in the Indonesian Passage are due to lack of enough drifter observations). The mean flow field displays the major currents of the region. The anticyclonic gyral circulation is characterized by the zonal broad South Equatorial Current, strong western boundary currents and weak eastern boundary currents. The Eastern Gyral Current extending from the Agulhas return flow is meandering towards the east.

The westward flowing South Equatorial Current (SEC)
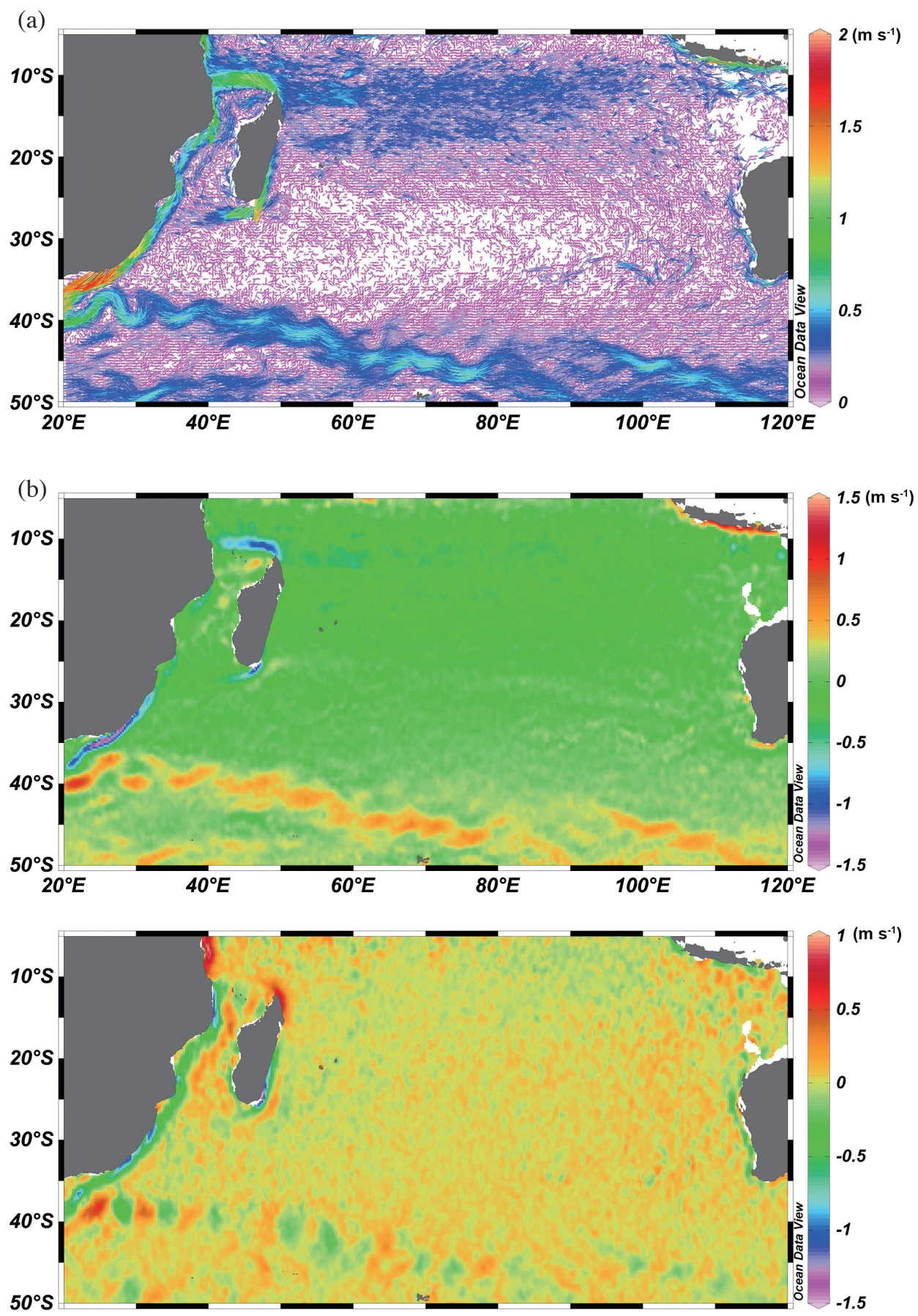

Fig. 4. (a) Mean surface velocity field of south Indian Ocean derived by combining satellite altimetry and surface drifter observations. (b) Mean velocity components. Upper panel: zonal; lower panel: meridional. 
dominates the surface circulation of the south Indian Ocean. The SEC is a more persistent current in the models as well as in the observations (Jensen 1993). As a direct consequence of basin-scale wind forcing combined with the Indonesian Throughflow (Godfrey and Golding 1981), the SEC flows between 10 and $20^{\circ} \mathrm{S}$. The SEC is composed of two broad current cores of velocity ranging between 0.25 and $0.5 \mathrm{~m} \mathrm{~s}^{-1}$. The major core of the current (northern) is around $12^{\circ} \mathrm{S}$, whereas the second core (southern) is around $18^{\circ} \mathrm{S}$. The major core originates from far eastern part of the Indian Ocean and is fed by the Indonesian Throughflow, whereas, the southern core is supported by the subtropical gyral circulation. North of the SEC, between 5 and $10^{\circ} \mathrm{S}$ weak cyclonic eddies are prevailing due to the shear between the SEC and the eastward flowing counter flow.

The mean velocity field displays powerful western boundary currents in the South Indian Ocean. The SEC attains its maximum speed and branches towards the west and south as it reaches the Madagascar Coast. The westward branch above the northern tip of Madagascar is again augmented and attains a speed of $1.5 \mathrm{~m} \mathrm{~s}^{-1}$ speed. The SEC branches as southward flow along the Mozambique Channel and northward as East African Coastal Current when it impinges into the east coast of Africa.

The southward flowing East Madagascar Current is strong and its velocity is above $1.5 \mathrm{~m} \mathrm{~s}^{-1}$ as it reaches the southern tip of Madagascar. A major portion of this current takes a south westward turn and merges with the Mozambique Current to form the Agulhas Current. A weak retroflection is also observed in the south eastern part of the Madagascar Current, where the flow slips from the coastal boundary (Lutjeharms 1988). The Agulhas Current depicts the highest speeds of above $1.5 \mathrm{~m} \mathrm{~s}^{-1}$ in the mean velocity field of south Indian Ocean. Even for a large stretch between 30 and $40^{\circ} \mathrm{S}$ the current speeds are above $1 \mathrm{~m} \mathrm{~s}^{-1}$. When this current reaches $40^{\circ} \mathrm{S}$ it undergoes retroflection, an abrupt anticyclonic turn and part of it returns to the south Indian Ocean. The Agulhas Return Current is eddy embedded and meandering, flowing towards the southeast with a speed ranging from 0.25 to $1 \mathrm{~m} \mathrm{~s}^{-1}$.

The mean velocity field exhibits weak circulation in the eastern part of the south Indian Ocean. A strong south eastward flow with a speed of $1 \mathrm{~m} \mathrm{~s}^{-1}$ prevails south of Java. The southward flowing Leeuwin Current is faintly visible in the mean field along the western coast of Australia, with a speed of around $0.5 \mathrm{~m} \mathrm{~s}^{-1}$. But, the poleward flow is much distracted between 25 and $30^{\circ} \mathrm{S}$ by zonal subtropical gyral component and eddy circulation is apparent.

The zonal and meridional components of the mean velocity field (Fig. 4b) show that both the components are strong at the western boundary current region. Zonal flow is predominant in most parts of the south Indian Ocean. Meridional component is also present in the meandering eastward flow along $40^{\circ} \mathrm{S}$.
The altimeter derived velocity anomaly field (Fig. 5), computed from the averages of anomaly velocities used to combine with drifter geostrophic velocity, serves as a correction to the simple averages of the drifter-derived velocities (Fig. 6). Although the large scale flow pattern is not much different from the simple average of drifter-derived velocities, the above mentioned correction by the altimeter-derived velocity anomaly shows significant differences along the peripherals and even an anomaly above $0.3 \mathrm{~m} \mathrm{~s}^{-1}$ is found at the Agulhas retroflection region. The anomaly field is also prominent in the zonal flows between 5 to $15^{\circ} \mathrm{S}$ and 35 to $45^{\circ} \mathrm{S}$. Largest anomaly is found south of Java. The Leeuwin Current regions also display a strong anomaly field.

The mean velocity field obtained in the present study shows good agreement with the global scale estimations of Pascual et al. (2006), Maximenko et al. (2009) and Rio et al. (2011). In particular, the mean velocity estimates of the western boundary of the Agulhas Current and East Madagascar are consistent with the CNES-CLS09 of Rio et al. (2011).

\subsection{Comparison with ADCP Data}

In order to validate the estimated velocity, we have computed the instantaneous velocity field using the time series altimeter-derived velocity anomaly field and the mean velocity field and compared it with the available in-situ velocities measured by the shipboard Acoustic Doppler Current Profiler (ADCP) data obtained from the WOCE cruises (WOCE Global Data version 3.0) of R/V Knorr (cruise id 180, 373, 500, 501) and R/V Franklin (id 339, 340). The depth of ADCP data used varies from $20-30 \mathrm{~m}$ and we assume that it represents the near surface geostrophic current. The instantaneous velocity estimated in this study is in good agreement with the ADCP derived velocities (Fig. 7). The regression lines fitted have slopes 0.89 and 0.87 for the $u$ and $v$ velocity components respectively and have correlation co-efficients of 0.89 and 0.88 respectively.

\subsection{Mesoscale Variability}

The Eulerian mean velocity field reflects the prevalence of mesoscale features in the flow field, especially in the western part of the south Indian Ocean, where an offshore enlargement of the mean current is evident. In order to understand the mesoscale activity, we have determined the kinetic energy distribution of mean and eddy flows. The ratios of the energy associated with the fluctuating motion to the energy associated with the mean flow and the eddy fluxes $\left(\left\langle u^{\prime} v^{\prime}\right\rangle\right)$ have also been analyzed.

The MKE distribution ranges between 0 and $1.2\left(\mathrm{~m} \mathrm{~s}^{-1}\right)^{2}$ in the south Indian Ocean (Fig. 8a). High energy is concentrated along the boundary current region and around $40^{\circ} \mathrm{S}$ latitude towards the east. The SEC depicts nearly $0.1\left(\mathrm{~m} \mathrm{~s}^{-1}\right)^{2}$ of energy in the east and central parts, but a substantial high 


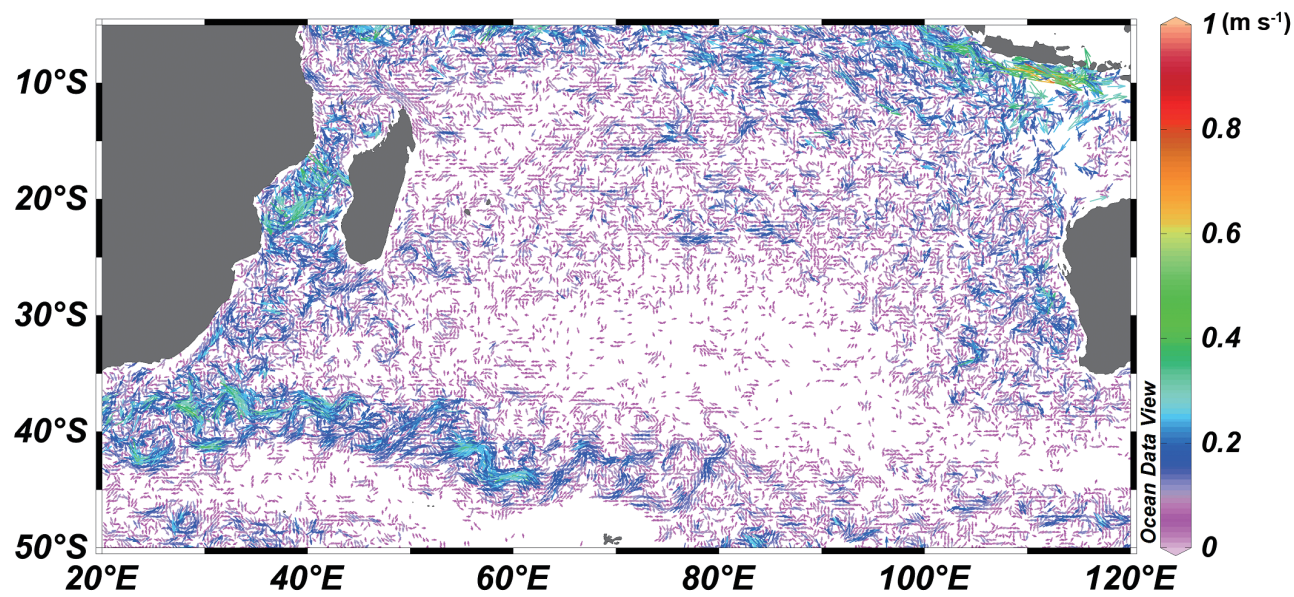

Fig. 5. Map of simple averages of geostrophic velocity anomaly $\left[\mathrm{Vg}^{\prime}(\mathrm{x}, \mathrm{t})\right]$ computed from altimeter data used for estimation of mean field.

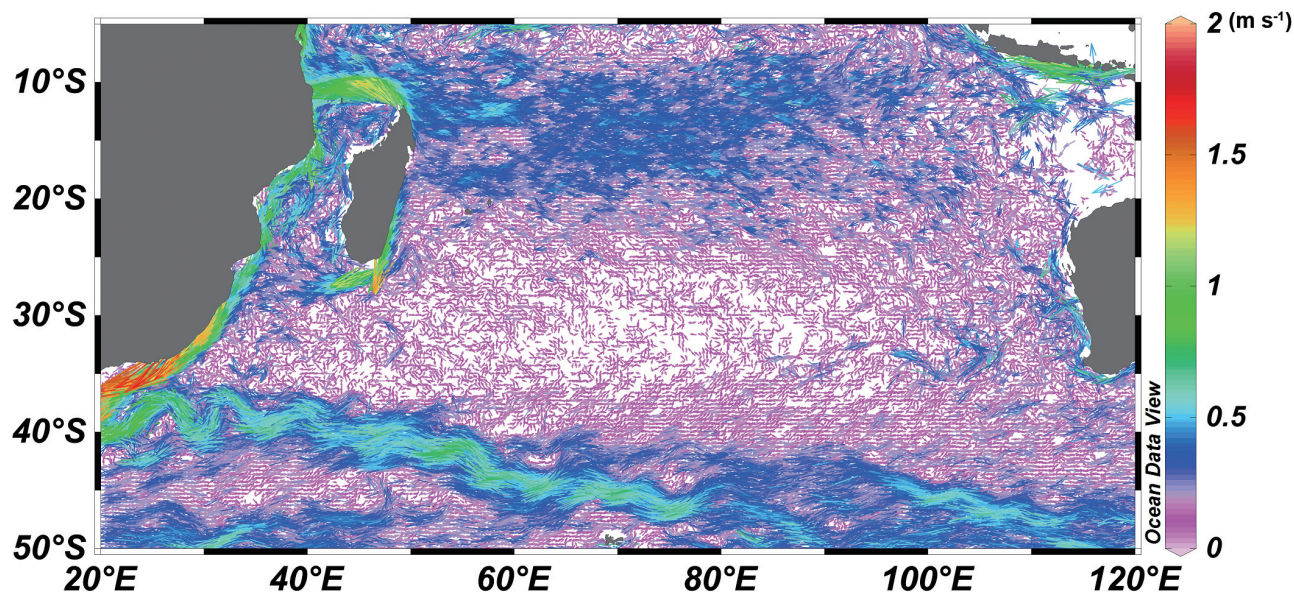

Fig. 6. Map of simple averages of instantaneous geostrophic velocity $[\operatorname{Vg}(\mathrm{x}, \mathrm{t})]$ estimated from drifter data used for estimation of mean field.
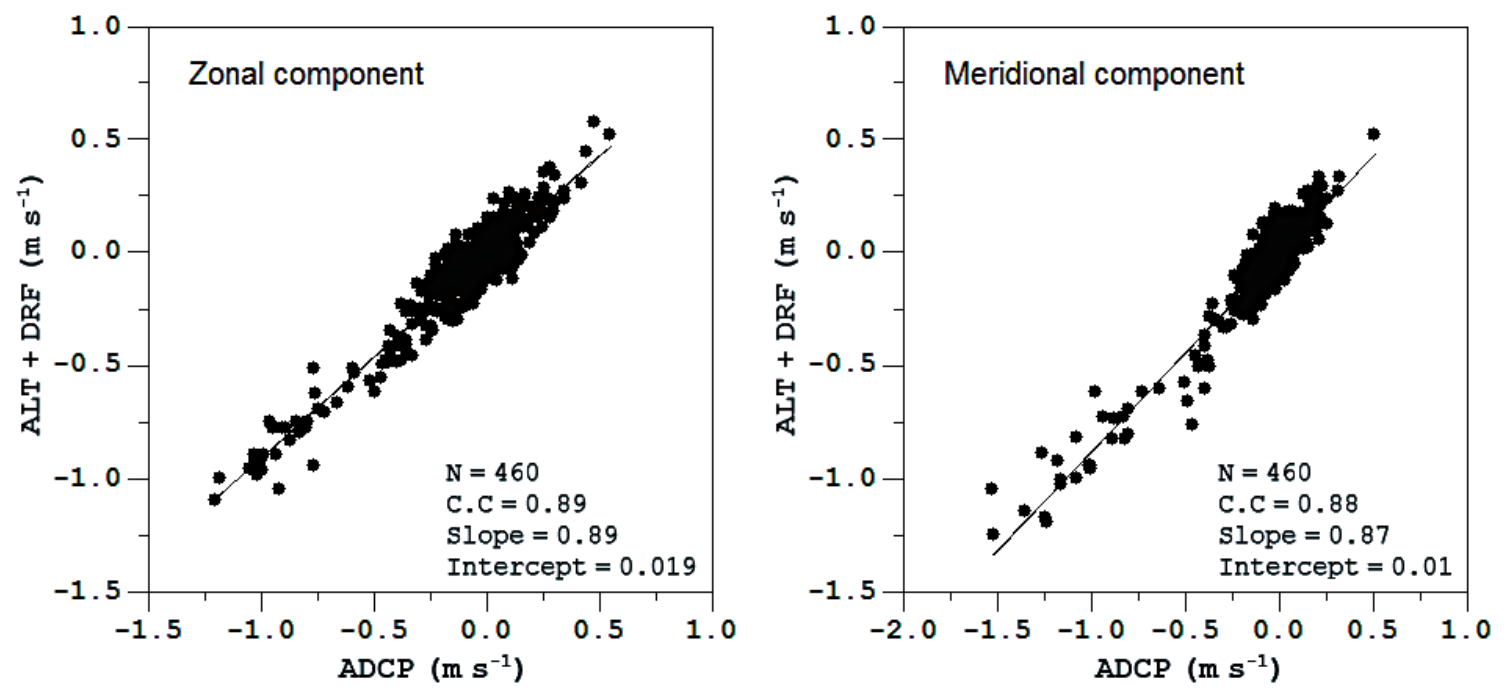

Fig. 7. Scatter plot of estimated instantaneous surface velocity components (ordinate) against ADCP-derived surface velocity components (abscissa). 

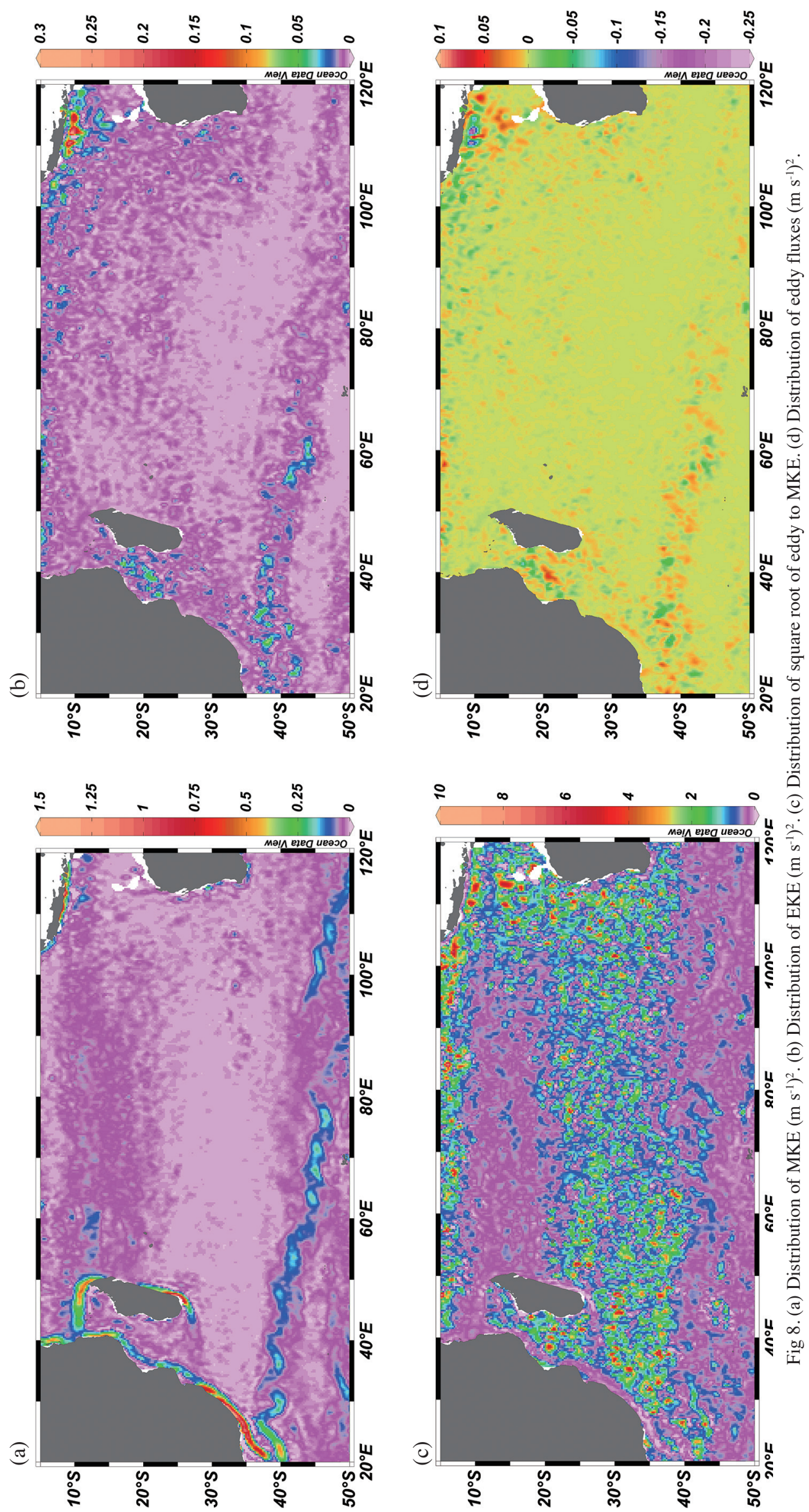
energy of up to $0.5\left(\mathrm{~m} \mathrm{~s}^{-1}\right)^{2}$ is noticed at the western end of the current around the tip of Madagascar to Africa. The maximum energy is associated with the Agulhas Current between 30 and $40^{\circ} \mathrm{S}$. MKE is also high south of Java (between 110 and $120^{\circ} \mathrm{E}$ ) and at the East Madagascar Current region. Central part $\left(25-35^{\circ} \mathrm{E}\right)$ of south Indian Ocean displays very low values of MKE.

In the south Indian Ocean, the EKE distribution (Fig. 8b) varies between 0 and $0.2\left(\mathrm{~m} \mathrm{~s}^{-1}\right)^{2}$. The central part of the Mozambique Channel and the Agulhas return current region (around $40^{\circ} \mathrm{S}$ and up to $60^{\circ} \mathrm{E}$ ), where the flows are embedded with eddies, exhibits high EKE. Low values are observed in the SEC region and between $25-35^{\circ} \mathrm{S}$ latitude. EKE is also very low in western boundary current (Agulhas Current region, East Madagascar Current) region whereas, high EKE is observed south of Java and west of Australia around $30^{\circ} \mathrm{S}$.

In the mean velocity field, along the western boundary between $25-40^{\circ} \mathrm{S}$ the current appears to be significantly intensified, flowing close to the coast. This agrees with the distributions of the energy associated with the mean flow (MKE) and the energy associated with the fluctuating motion (EKE), where, a significant increase in the MKE occurs simultaneously with a reduction in the level of EKE. It is remarkable that, within such an area the field becomes more uniform and the MKE attains its maximum values, affirming the transfer of energy from the eddy field to the mean current.

The ratio of EKE to MKE is also examined. In order to keep the scaling linear, we have taken the square root. By comparing the distribution $\sqrt{ }$ (EKE/MKE) with of eddy fluxes, we can investigate whether eddies are locally formed or they have drifted into the area (Jakobsen et al. 2003).

High values of $\sqrt{ }$ (EKE/MKE) are observed along the offshore side of the western boundary current region and in the central part of the subtropical gyre between $20-30^{\circ} \mathrm{S}$ (Fig. 8c). Minimum of this ratio is at the Agulhas retroflection region, along the meandering flow around $40^{\circ} \mathrm{S}$ and in the SEC region. In the central part of south Indian Ocean between $25-35^{\circ} \mathrm{S}$ the energy ratio remains maximum, indicating weak mean flow. The distribution clearly distinguishes the stable mean flow occurring in the SEC region, except in the eastern part. The northern part between $5-7^{\circ} \mathrm{S}$ exhibits high energy ratio because of the presence of eddies due to the shear between the SEC and the Equatorial Counter Current. High energy ratio is also noticed in the central and eastern side of the Mozambique Channel where eddy circulation is dominant.

The distribution of eddy fluxes shows positive and negative fluxes (Fig. 8d). At the western boundary current regions and in the central part of the basin positive fluxes prevail whereas, negative fluxes are dominant in the central part of the Mozambique Channel and along the Java coast. High eddy flux is observed in the western side of the Mozambique Channel at around $20^{\circ} \mathrm{S}$, which coincides with high $\sqrt{ }(\mathrm{EKE} / \mathrm{MKE})$, indicating that the eddies in this region are locally formed. Eddy flux distribution around $40^{\circ} \mathrm{S}$ along the Agulhas Return Current towards the east is also quite notable. In the retroflection region the eddy fluxes are negative and then positive between $35-45^{\circ} \mathrm{S}$. Again, negative fluxes are observed at around $60^{\circ} \mathrm{E}$. These alternate positive and negative fluxes indicate the eddy flux convergence in this region (Morrow et al. 1994). The flux distribution shows that the eddy fluxes are almost nil in the SEC region.

Thus, intense mesoscale variability occurs south of Java, the Mozambique Channel and along the Agulhas Return Current region in the south Indian Ocean. Both baroclinic and barotropic instability processes are important in explaining observed eddy variability. The stability analysis (Palastanga et al. 2007) shows that the SEC vertical shear is stable, except in the eastern part. Matano et al. (2008) attributes that the seasonal variability of the south Indian Ocean circulation is driven by the Indonesian throughflow and local wind forcing. Also, the influence of throughflow, however, seems to be confined to the easternmost portion of the basin while the wind stress forcing is important everywhere. This study indicates that the baroclinically unstable system might result in the development of high EKE in the region south off Java. The baroclinic instability is triggered by the abrupt reversal of flow south of Java and the instability drew most energy from the available potential energy associated with the throughflow.

The mechanisms identified for the eddy formation in the Mozambique Channel are barotropic instability of the SEC north of Madagascar and the shedding related to the geometry of the narrow section of Mozambique Channel during strong current events when the northern anticyclonic loop is pushed through the constriction (Ridderinkhof and de Ruijter 2003). Thus, the horizontal shear developed by barotropic instability is powered the eddy activity in the Mozambique Channel. The Agulhas Current region is identified as one of the most energetic parts of the world's oceans and the warm core rings generated at the Agulhas retroflection are some of the strongest ever observed (Thomson and Demirov 2006). Eddy activity west of Australia is related to the Leeuwin Current variability as well as the impacts from the tropical ocean via Indonesian Throughflow. Eddies and baroclinic Rossby waves are found to be generated by the Leeuwin Current variations and they propagate to the west (Jia et al. 2011).

\subsection{Seasonal Circulation}

In order to understand the annual cycle of currents in the south Indian Ocean we have estimated a twenty year average of monthly absolute velocities and are presented for January, April, July and October. The maps prepared on regional basis illustrate the intra-annual variations occurring in the surface currents of the south Indian Ocean. 


\subsubsection{Tropical South Indian Ocean}

In January, the SEC is strong and its speed ranges between 0.25 and $1 \mathrm{~m} \mathrm{~s}^{-1}$ (Fig. 9). The current occurs between 8 and $20^{\circ} \mathrm{S}$ latitude and portrays a meandering flow pattern in the central part. Higher speeds of $1 \mathrm{~m} \mathrm{~s}^{-1}$ are noticed in the western side, above the northern tip of Madagascar to Africa. Also, the northern core is prominent during this period. Indonesian Throughflow is weak and south eastward current prevails south off Java. In the Mozambique Channel a strong southward flow occurs along the western coast and an anticyclonic eddy circulation in the eastern part.

Conspicuous changes are developed by April in the SEC. It is strengthened and the meandering structure has disappeared. Also, the current has become narrow and its meridional extent is limited between 10 and $20^{\circ} \mathrm{S}$. Both the current cores are clearly visible. The flow is further strengthened in the western part between Madagascar and Africa where current speeds are above $1 \mathrm{~m} \mathrm{~s}^{-1}$. Eastward flow of the Equatorial Counter Current is visible between 5 and $7^{\circ} \mathrm{S}$ with speeds up to $0.5 \mathrm{~m} \mathrm{~s}^{-1}$. The boundary region between SEC and Equatorial Current is dominated by a weak eddy circulation. The eastward coastal flow along the Java coast is also slightly weakened but, the Indonesian Throughflow is more developed in this period.

In July, the SEC is again narrowed and the flow is lim- ited to between 12 and $18^{\circ} \mathrm{S}$. The flow is much weakened compared to April in the central and eastern parts (less than $0.5 \mathrm{~m} \mathrm{~s}^{-1}$ ), whereas broad and intensified flow (above $1 \mathrm{~m} \mathrm{~s}^{-1}$ ) still prevails in the western side between 35 and $45^{\circ} \mathrm{E}$. Further, the Equatorial Counter Current is also weakened on the northern side. Indonesian throughflow is intensified and a broad westward flow occupies south off Java which finally joins the northern core of the SEC. But, the southern core of the SEC is weakened in July compared to April.

By October, the SEC has regained its strength in the eastern part of the south Indian Ocean but, weakened in the west between Madagascar and Africa. It also has become wide, occurring between 8 and $20^{\circ} \mathrm{S}$, and displaying a meandering pattern. Another conspicuous change noticed during this period is the break in its zonal structure at around $80^{\circ} \mathrm{E}$, where the northern core of the current takes a latitudinal shift to the south. The throughflow and westward flow south of Java still prevails but, is slightly weakened compared to July.

In the southern tropical Indian Ocean the broad zonal flow of the SEC shows variations in its magnitude and location with respect to season. The latitudinal shift of the SEC is clearly revealed in the maps that in southern hemisphere summer the current is wider, irregular and slightly weaker compared to winter season. SEC is more shifted to south and well organized flow in southern hemisphere winter. A

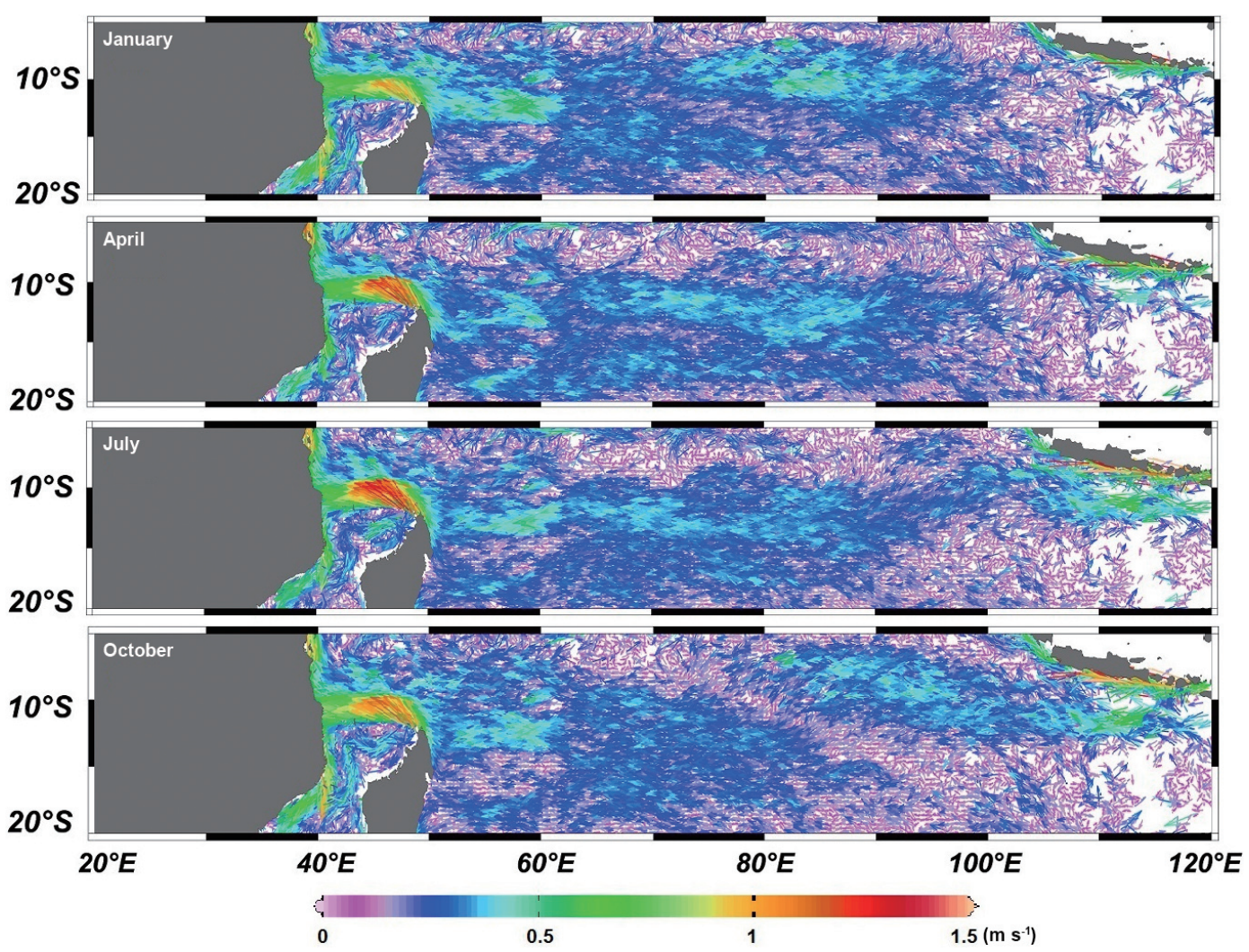

Fig. 9. Average absolute surface velocity field of the tropical south Indian Ocean (1993 - 2012). 
similar latitudinal shift is also observed from hydrographic observations (Benny and Mizuno 2000). Seasonal variations of the Indonesian Throughflow are obviously visible as shown on the maps. The throughflow component is broad and strong in July and October is consistent with the observations of Meyers et al. (1995). The irregular pattern of the SEC is because of the effects of bottom topography and Rossby wave activity (Schott and McCreary 2001).

\subsubsection{Southwest Indian Ocean}

In the western part of southwest Indian Ocean, the flow is quite strong along the Mozambique Coast and eddy circulation is dominant in the channel during January (Fig. 10). The EMC is strong and it attains speed above $1 \mathrm{~m} \mathrm{~s}^{-1}$ as it reaches the southern end of Madagascar. The major part of EMC turns westward to join the Mozambique current at around $27^{\circ} \mathrm{S}$ and it finally flows as the Agulhas Current. The Agulhas Current attains a speed of above $1.5 \mathrm{~m} \mathrm{~s}^{-1}$ between $30-40^{\circ} \mathrm{S}$ and it retroflects at around $40^{\circ} \mathrm{S}$. The return current is highly meandering and flows southeastward. Eddy circulation prevails in the region between $35-45^{\circ} \mathrm{S}$ and $20-30^{\circ} \mathrm{E}$.

In April, a slight change observed is in the westward component of East Madagascar Current which is quite intensified between 35 and $40^{\circ} \mathrm{E}$. The Agulhas Current is the same as in January. A conspicuous change noticed in July is the weakening of the EMC and its westward component south of Madagascar. The Mozambique Current also is weak. These changes are reflected on the Agulhas Current as its speed is below $2 \mathrm{~m} \mathrm{~s}^{-1}$. This weakening of western boundary circulation is due to the weakening of the southern core of the SEC. In October, no significant changes are observed in the southwest Indian Ocean compared to July. The Agulhas Current is almost the same as in July.

Thus, the western boundary currents of the south Indian Ocean show an active circulation system and they are seasonally modulated by the zonal variations of SEC. The Agulhas Current clearly shows seasonal changes with strong flow in southern hemisphere summer and slightly weakened in winter. Considerable variability has been reported in the Agulhas Current (Ffield et al. 1997; Matano et al. 2002; Reason et al. 2003). The Agulhas Current region and its sources are highly variable on eddy, seasonal and interannual time scales. Slight variations are also found in the East Madagascar Current and are related to the changes in the southern core of the SEC. Hermes et al. (2007) found annual and semiannual signals in the East Madagascar Current

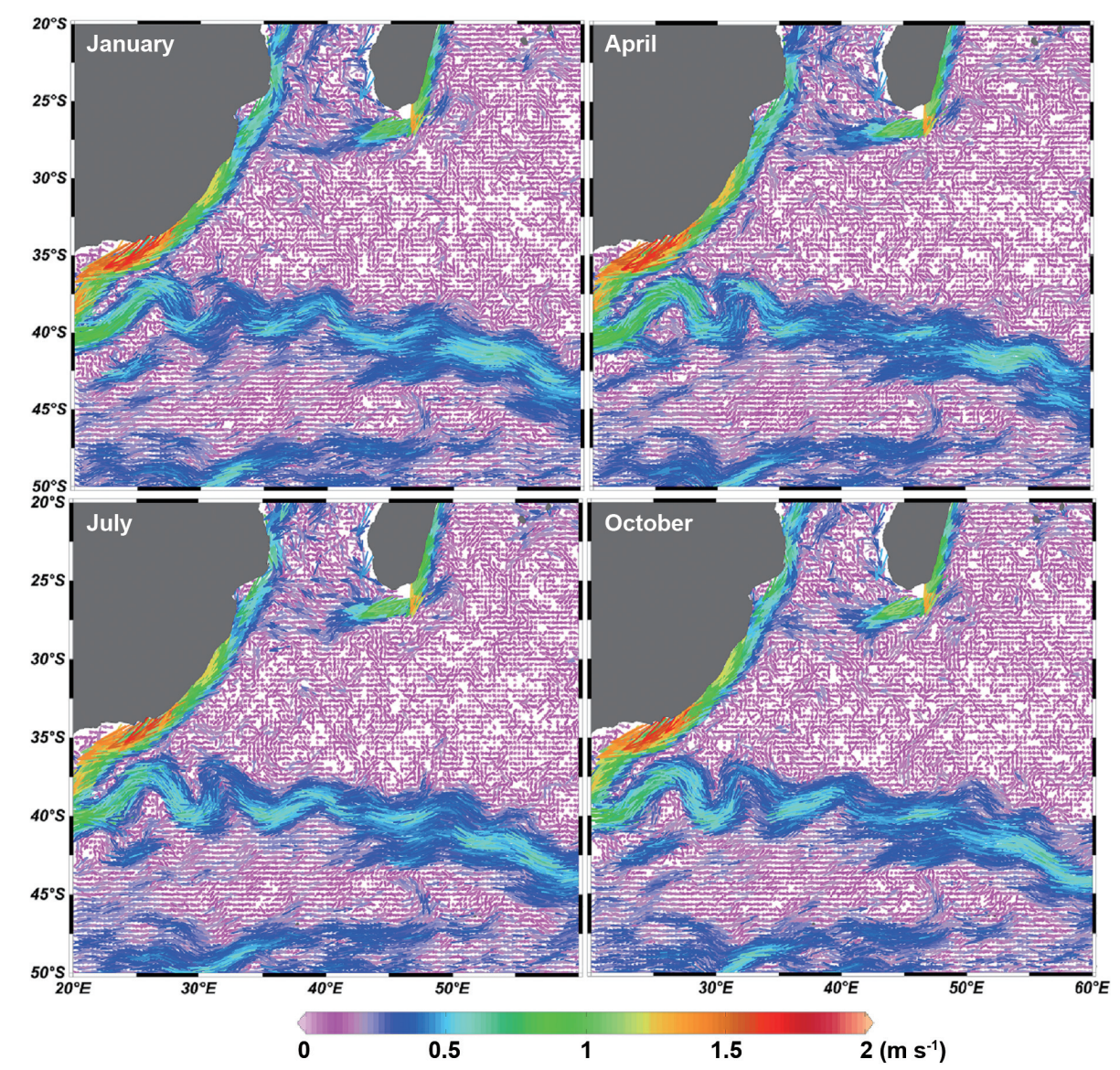

Fig. 10. Average absolute surface velocity field of the southwest Indian Ocean (1993 - 2012). 
at $20^{\circ} \mathrm{S}$ and attribute this variability to the local wind stress curl and partly to the variability in the southern branch of the SEC.

\subsubsection{Southeast Indian Ocean}

The southward flowing Leeuwin Current is faintly visible in January along the northeast coast of Australia (Fig. 11). At around $28^{\circ} \mathrm{S}$ the southward flow diverts and an onshore flow occurs between 28 and $30^{\circ} \mathrm{S}$. But, again southward coastal current is present beyond $32^{\circ} \mathrm{S}$ towards south and eastward around the coast. In April, the Leeuwin Current is well developed in the northern part up to $28^{\circ} \mathrm{S}$, and the coastal flow beyond $32^{\circ} \mathrm{S}$ is also strengthened. Between 26 and $28^{\circ} \mathrm{S}$ the onshore current speed reaches above $0.5 \mathrm{~m} \mathrm{~s}^{-1}$. By July, the Leeuwin Current is weakened in the northern part between 22 and $28^{\circ} \mathrm{S}$. But, the southward coastal flow is still strong beyond $32^{\circ} \mathrm{S}$. The Leeuwin Current is again weakened in the northern part in October. An anticyclonic eddy circulation is present between 30 and $35^{\circ} \mathrm{S}$ and $100-110^{\circ} \mathrm{E}$ throughout the year.

Thus, the southeastern Indian Ocean shows dull circulation compared to the tropical and western parts. The pole- ward flowing Leeuwin Current along the west coast of Australia is observed in all the months but, it shows seasonal and spatial variations. The strong flow obtained in April and July agrees with the observations by Cresswell and Golding (1980). Pearce and Cresswell (1985) found that the Leeuwin Current is strongest during southern hemisphere autumn and winter (April - August) and it is weakened by November.

\subsection{Zonal Surface Velocity of the SEC}

The above results reveal that the SEC is highly variable in the south Indian Ocean. Therefore, the zonal components of surface velocity at 60 and $80^{\circ} \mathrm{E}$ for different seasons are presented with respect to latitude to understand the spatial and seasonal variability of the SEC (Fig. 12).

\subsubsection{At $60^{\circ} \mathrm{E}$}

The SEC has no significant seasonal variation in zonal speed at $60^{\circ} \mathrm{E}$. The major core of the SEC is around $12.5^{\circ} \mathrm{S}$, where the zonal current speeds reach almost $0.5 \mathrm{~m} \mathrm{~s}^{-1}$ in January and July. The current speed is almost around $0.25 \mathrm{~m} \mathrm{~s}^{-1}$ in the southern part, whereas in the northern part current

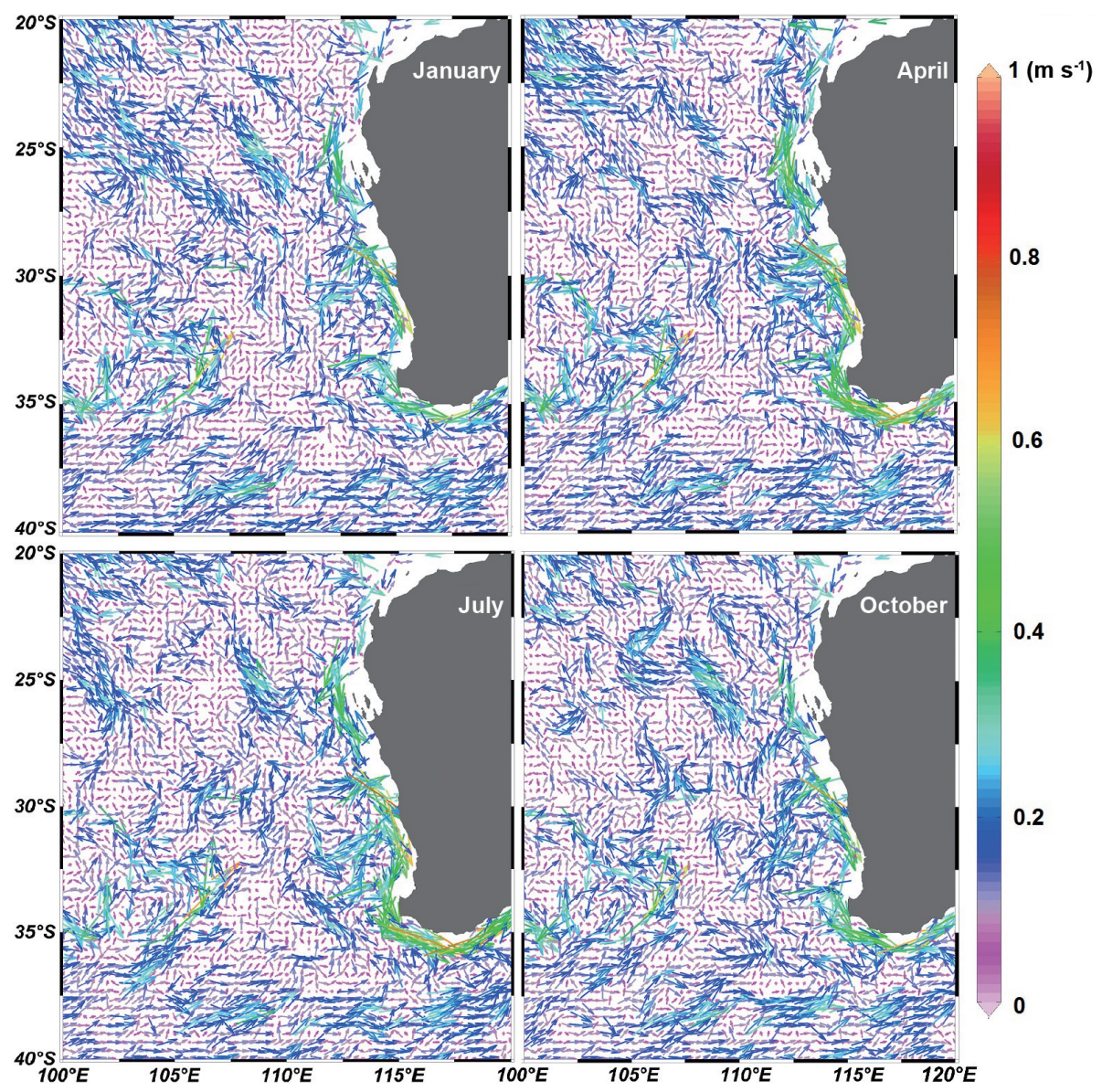

Fig. 11. Average absolute surface velocity field of the southeast Indian Ocean (1993 - 2012). 

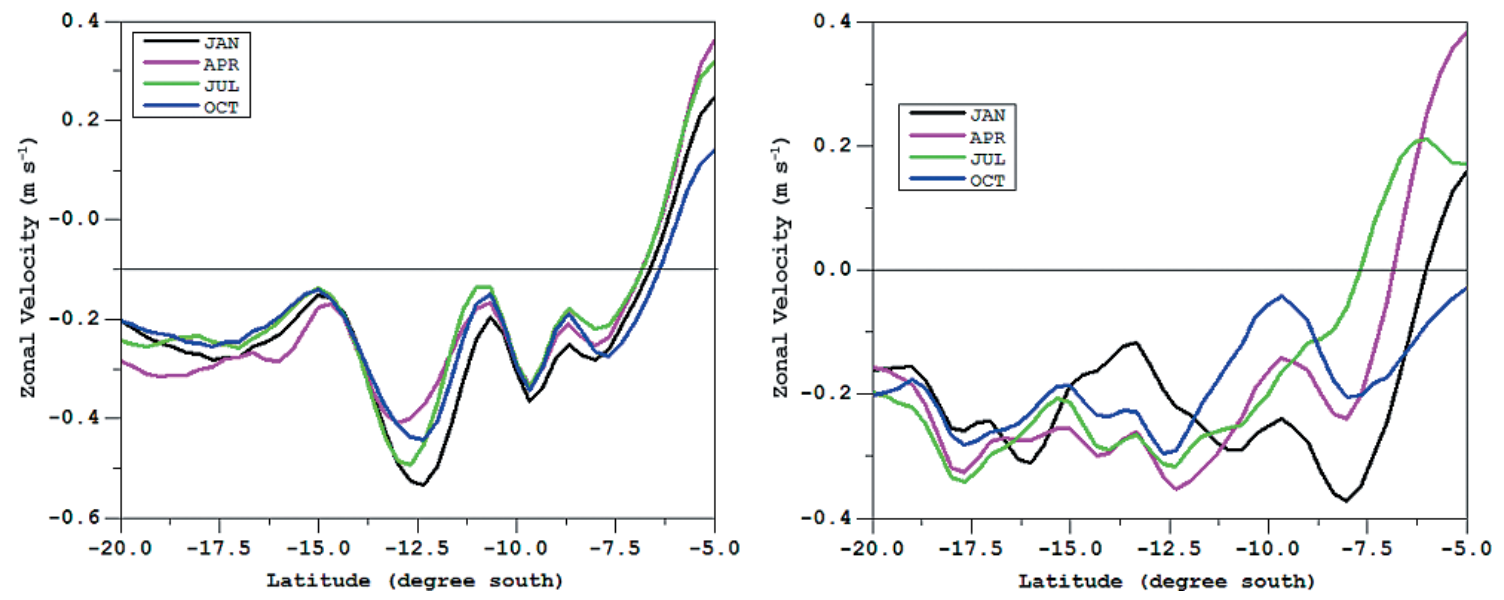

Fig. 12. Zonal velocity distribution between 5 and $20^{\circ} \mathrm{S}$. Left panel: at $60^{\circ} \mathrm{E}$; right panel: at $80^{\circ} \mathrm{E}$.

is weak and more varying. A seasonal variation of about $0.1 \mathrm{~m} \mathrm{~s}^{-1}$ is noticed which is dominant in the southern part. In April, the zonal current is more evenly distributed. The northern boundary of the SEC is at around $7^{\circ} \mathrm{S}$ where the eastward counter current begins. The counter current is strong in April and July with speeds up to $0.3 \mathrm{~m} \mathrm{~s}^{-1}$.

\subsubsection{At $80^{\circ} \mathrm{E}$}

The zonal current distribution is different at $80^{\circ} \mathrm{E}$ compared to $60^{\circ} \mathrm{E}$. Significant spatial and temporal variations are found. The SEC exhibits the multi-core structure at $80^{\circ} \mathrm{E}$. The major current core is around $12.5^{\circ} \mathrm{S}$ as in $60^{\circ} \mathrm{E}$ in April, July and October. But, in January the major core shifted to lower latitudes of around $8^{\circ} \mathrm{S}$. The second core of the SEC is around $18^{\circ} \mathrm{S}$ during April, July and October but, in January it is around $16^{\circ} \mathrm{S}$. The current speed varies much in the northern part. In January, the eastward flowing counter current occupies from $6^{\circ} \mathrm{S}$ towards the equator whereas, during April and July the counter current is present even from 7.5 and $8^{\circ} \mathrm{S}$. It is interesting to note that no part of eastward flow is present in October throughout the section $\left(5-20^{\circ} \mathrm{S}\right)$.

The velocity distribution along 60 and $80^{\circ} \mathrm{E}$ illustrates the seasonal variation and the irregular nature of the SEC. Interestingly, in the western part the current shows stable pattern and weak seasonal changes compared to the east. The irregular pattern at $80^{\circ} \mathrm{E}$ is related to throughflow variations, Rossby wave activity and bottom topographic effects. As the southwest monsoon ceases by September, the eastward counter current is weakened in the equatorial part. Hence, the westward flow run by the Indonesian Throughflow extends more into the lower latitudes in October.

\section{SUMMARY}

Merging satellite altimetry and satellite tracked surface drifter observations the present study brings out the mean and seasonal variability of south Indian Ocean circulation. The mean field depicts the major currents of south Indian Ocean. The Agulhas Current is the fastest current in the south Indian Ocean and its mean speed reaches above $1.5 \mathrm{~m} \mathrm{~s}^{-1}$. The southward flowing Leeuwin Current (eastern boundary current) is not obvious, but a strong southeastward flow is observed south of Java in the mean filed. Mesoscale variability is dominant along the Mozambique Channel, Agulhas retroflection region and south off Java. Eddy-mean current interactions occur along the western boundary as well as around $40^{\circ} \mathrm{S}$ latitude. The seasonal changes of Indonesian Throughflow, South Java Current and the SEC are playing significant roles in the mesoscale variability of the south Indian Ocean.

The monthly surface circulation pattern illustrates spatial and temporal variations in the flow field. Among the surface currents, the SEC is subjected to a latitudinal shift as well changes in its structure and characteristics. The SEC is a strong, broad and meandering structure in the southern hemisphere summer period, whereas it is weak and narrow in winter. Also, the variation is more in the east and the major core of the SEC shows east-west sloping. The seasonal flow pattern clearly confirms the dipole signal in the tropical south Indian Ocean. The East Madagascar Current and Agulhas Current show slight seasonal changes due to the variations in the SEC. The Agulhas Current is faster in summer. In the eastern boundary the Leeuwin Current also shows seasonal variations.

Acknowledgements We used the altimeter data set produced by the CLS, Space Oceanography Division as part of Environment and Climate. Drifter data produced by the National Oceanic and Atmospheric Administration, Atlantic Oceanographic and Meteorological Laboratory were utilized. Also employed was the wind data set produced and provided by the French Processing and Archiving Facility (CERSAT) 
at the French Research Institute for Exploration of the Sea. We used Ocean Data View (ODV) software, Schlitzer, R., http://odv.awi.de, 2013, for preparing graphics. The first author acknowledges financial support for the work from UTM short term research grants Vote no. 4D024.

\section{REFERENCES}

Archiving, Validation, and Interpretation of Satellite Oceanographic Data (AVISO), 1997: AVISO Handbook: Sea Level Anomaly Files, $21^{\text {st }}$ Ed., France, 24 pp.

Beal, L. M. and H. L. Bryden, 1999: The velocity and vorticity structure of the Agulhas Current at $32^{\circ}$ S. J. Geophys. Res., 104, 5151-5176, doi: 10.1029/1998JC900056. [Link]

Beal, L. M., W. P. M. De Ruijter, A. Biastoch, R. Zahn, and SCOR/WCRP/IAPSO Working Group 136, 2011: On the role of the Agulhas system in ocean circulation and climate. Nature, 472, 429-436, doi: 10.1038/ nature09983. [Link]

Bennett, S. L., 1988: Where three oceans meet: The Agulhas retroflection region. Ph.D. Thesis, Dept. of Earth, Atmospheric, and Planetary Sciences, Massachusetts Institute of Technology, WHOI-88-51, $217 \mathrm{pp}$.

Benny, N. P. and K. Mizuno, 2000: Annual cycle of steric height in the Indian Ocean estimated from the thermal field. Deep-Sea Res. Part I-Oceanogr. Res. Pap., 47, 1351-1368, doi: 10.1016/S0967-0637(99)00088-6. [Link]

Benny, N. P., P. Sreeraj, and K. G. V. Kumar, 2005: Structure and variability of the Leeuwin Current in the south eastern Indian Ocean. J. Ind. Geophys. Union, 9, 107-119.

Biastoch, A., C. J. C. Reason, J. R. E. Lutjeharms, and O. Boebel, 1999: The importance of flow in the Mozambique Channel to seasonality in the greater Agulhas Current system. Geophys. Res. Lett., 26, 3321-3324, doi: 10.1029/1999GL002349. [Link]

Bray, N. A., S. Hautala, J. Chong, and J. Pariwono, 1996: Large-scale sea level, thermocline, and wind variations in the Indonesian throughflow region.J. Geophys. Res., 101, 12239-12254, doi: 10.1029/96JC00080. [Link]

Bryden, H. L. and L. M. Beal, 2001: Role of the Agulhas Current in Indian Ocean circulation and associated heat and freshwater fluxes. Deep-Sea Res. Part I-Oceanogr. Res. Pap., 48, 1821-1845, doi: 10.1016/ S0967-0637(00)00111-4. [Link]

Cresswell, G. R. and T. J. Golding, 1980: Observations of a south-flowing current in the southeastern Indian Ocean. Deep-Sea Res. Part I-Oceanogr. Res. Pap., 27, 449-466, doi: 10.1016/0198-0149(80)90055-2. [Link]

de Ruijter, W. P. M., H. Ridderinkhof, J. R. E. Lutjeharms, M. W. Schouten, and C. Veth, 2002: Observations of the flow in the Mozambique Channel. Geophys. Res. Lett., 29, 140-1-140-3, doi: 10.1029/2001GL013714. [Link]
Divakaran, P. and G. B. Brassington, 2011: Arterial ocean circulation of the southeast Indian Ocean. Geophys. Res. Lett., 38, L01802, doi: 10.1029/2010GL045574. [Link]

Ducet, N., P. Y. Le Traon, and G. Reverdin, 2000: Global high-resolution mapping of ocean circulation from TOPEX/Poseidon and ERS-1 and -2. J. Geophys. Res., 105, 19477-19498, doi: 10.1029/2000JC900063. [Link]

Emery, W. J. and R. E. Thomson, 2001: Data Analysis Methods in Physical Oceanography, 2nd Edition, Elsevier Science, New York, 654 pp.

Feng, M., G. Meyers, A. Pearce, and S. Wijffels, 2003: Annual and interannual variations of the Leeuwin Current at $32^{\circ} \mathrm{S}$. J. Geophys. Res., 108, doi: 10.1029/2002JC001763. [Link]

Ffield, A. F., J. Toole, and D. Wilson, 1997: Seasonal circulation in the South Indian Ocean. Geophys. Res. Lett., 24, 2773- 2776, doi: 10.1029/97GL01253. [Link]

Godfrey, J. S. and T. J. Golding, 1981: The Sverdrup relation in the Indian Ocean, and the effect of Pacific-Indian Ocean Throughflow on Indian Ocean circulation and on the East Australian Current. J. Phys. Oceanogr., 11, 771-779, doi: 10.1175/1520-0485(1981)011< 0771:TSRITI>2.0.CO;2. [Link]

Gordon, A. L., 1985: Indian-Atlantic transfer of thermocline water at the Agulhas retroflection. Science, 227, 1030-1033.

Gordon, A. L., 2003: Oceanography: The brawniest retroflection. Nature, 421, 904-905, doi: 10.1038/421904a. [Link]

Gordon, A. L., J. R. E. Lutjeharms, and M. L. Gründlingh, 1987: Stratification and circulation at the Agulhas Retroflection. Deep-Sea Res. Part I-Oceanogr. Res. Pap., 34, 565-599, doi: 10.1016/0198-0149(87)90006-9. [Link]

Gordon, A. L., R. D. Susanto, and A. Ffield, 1999: Throughflow within Makassar Strait. Geophys. Res. Lett., 26, 3325-3328.

Gründlingh, M. L., R. A. Carter, and R. C. Stanton, 1991: Circulation and water properties of the southwest Indian Ocean, Spring 1987. Prog. Oceanogr., 28, 305-342, doi: 10.1016/0079-6611(91)90031-G. [Link]

Hansen, D. V. and P. M. Poulain, 1996: Quality control and interpolations of WOCE-TOGA drifter data. J. Atmos. Ocean. Technol., 13, 900-909, doi: 10.1175/1520-042 6(1996)013<0900:QCAIOW>2.0.CO;2. [Link]

Hermes, J. C., C. J. C. Reason, and J. R. E. Lutjeharms, 2007: Modeling the variability of the greater Agulhas current system. J. Climate, 20, 3131-3146, doi: 10.1175/JCLI4154.1. [Link]

Jacobs, S. S. and D. T. Georgi, 1977: Observations on the southwest Indian/Antarctic Ocean. In: Angel, M. (Ed.), A Voyage of Discovery, Pergamon Press, Oxford, 43-84.

Jakobsen,P.K., M.H. Ribergaard,D.Quadfasel, T. Schmith, 
and C. W. Hughes, 2003: Near-surface circulation in the northern North Atlantic as inferred from Lagrangian drifters: Variability from the mesoscale to interannual. J. Geophys. Res., 108, doi: 10.1029/2002JC001554. [Link]

Jensen, T. G., 1993: Equatorial variability and resonance in a wind-driven Indian Ocean model. J. Geophys. Res., 98, 22533-22552, doi: 10.1029/93JC02565. [Link]

Jia, F., L. Wu, J. Lan, and B. Qiu, 2011: Interannual modulation of eddy kinetic energy in the southeast Indian Ocean by Southern Annular Mode. J. Geophys. Res., 116, C02029, doi: 10.1029/2010JC006699. [Link]

Kindle, J. C. and J. D. Thompson, 1989: The 26- and 50day oscillations in the western Indian Ocean: Model results. J. Geophys. Res., 94, 4721-4736, doi: 10.1029/ JC094iC04p04721. [Link]

Lutjeharms, J. R. E., 1988: Remote sensing corroboration of retroflection of the East Madagascar Current. DeepSea Res. Part I-Oceanogr. Res. Pap., 35, 2045-2050, doi: 10.1016/0198-0149(88)90124-0. [Link]

Lutjeharms, J. R. E., 1996: The exchange of water between the South Indian and South Atlantic Oceans. In: Wefer, G., W. H. Berger, G. Siedler, and D. J. Webb (Eds.), The South Atlantic: Present and Past Circulation, Springer-Verlag Berlin Heidelberg, 125-162, doi: 10.1007/978-3-642-80353-6_8. [Link]

Lutjeharms, J. R. E., 2006: The Agulhas Current, Springer, $329 \mathrm{pp}$.

Matano, R. P., E. J. Beier, P. T. Strub, and R. Tokmakian, 2002: Large-scale forcing of the Agulhas variability: The seasonal cycle. J. Phys. Oceanogr., 32, 12281241, doi: 10.1175/1520-0485(2002)032<1228:LSFOTA>2.0.CO;2. [Link]

Matano, R. P., E. J. Beier, and P. T. Strub, 2008: The seasonal variability of the circulation in the South Indian Ocean: Model and observations. J. Mar. Syst., 74, 315328, doi: 10.1016/j.jmarsys .2008.01.007. [Link]

Maximenko, N., P. Niiler, M. H. Rio, O. Melnichenko, L. Centurioni, D. Chambers, V. Zlotnicki, and B. Galperin, 2009: Mean dynamic topography of the ocean derived from Satellite and drifting buoy data using three different techniques. J. Atmos. Ocean. Technol., 26, 1910-1919, doi: 10.1175/2009JTECHO672.1. [Link]

Meyers, G., R. J. Bailey, and A. P. Worby, 1995: Geostrophic transport of indonesian throughflow. DeepSea Res. Part I-Oceanogr. Res. Pap., 42, 1163-1174, doi: 10.1016/0967-0637(95)00037-7. [Link]

Molinari, R. L., D. Olson, and G. Reverdin, 1990: Surface current distributions in the tropical Indian Ocean derived from compilations of surface buoy trajectories. J. Geophys. Res., 95, 7217- 7238, doi: 10.1029/ JC095iC05p07217. [Link]

Morrow R., R. Coleman, J. Church, and D. Chelton, 1994: Surface eddy momentum flux and velocity variances in the Southern Ocean from Geosat Altimetry. J. Phys. Oceanogr., 24, 2050-2071, doi: 10.1175/1520-0485(1 994)024<2050:SEMFAV>2.0.CO;2. [Link]

Morrow, R., F. Fang, M. Fieux, and R. Molcard, 2003: Anatomy of three warm-core Leeuwin Current eddies. Deep-Sea Res. Part II-Top. Stud. Oceanogr., 50, 22292243, doi: 10.1016/S0967-0645(03)00054-7. [Link]

Niiler, P., 2001: The world ocean surface circulation. In: Siedler, G., J. Church, J. Gould, and W. J. Gould (Eds.), Ocean Circulation and Climate: Observing and Modelling the Global Ocean, Academic Press, 193-204.

Niiler, P. P. and J. D. Paduan, 1995: Wind-driven motions in the northeast Pacific as measured by Lagrangian drifters. J. Phys. Oceanogr., 25, 2819-2830, doi: 10.1175/ 1520-0485(1995)025<2819:WDMITN>2.0.CO;2. [Link]

Palastanga, V., P. J. van Leeuwen, and W. P. M. de Ruijter, 2006: A link between low-frequency mesoscale eddy variability around Madagascar and the large-scale Indian Ocean variability. J. Geophys. Res., 111, C09029, doi: 10.1029/2005JC003081. [Link]

Palastanga, V., P. J. van Leeuwen, M. W. Schouten, and W. P. M. de Ruijter, 2007: Flow structure and variability in the subtropical Indian Ocean: Instability of the South Indian Ocean Countercurrent. J. Geophys. Res., 112, C01001, doi: 10.1029/2005JC003395. [Link]

Pascual, A., Y. Faugère, G. Larnicol, and P. Y. Le Traon, 2006: Improved description of the ocean mesoscale variability by combining four satellite altimeters. Geophys. Res. Lett., 33, L02611, doi: 10.1029/2005GL024633. [Link]

Pazan, S. E. and P. P. Niiler, 2001: Recovery of near-surface velocity from undrogued drifters. J. Atmos. Ocean. Technol., 18, 476-489, doi: 10.1175/1520-0426(2001 )018<0476:RONSVF>2.0.CO;2. [Link]

Pearce, A. F. and G. R. Cresswell, 1985: Ocean circulation off Western Australia and Leeuwin Current. CSIRO Inf. Sheet, 16-3, 4 pp.

Qu, T. and G. Meyers, 2005: Seasonal characteristics of circulation in the southeastern tropical Indian Ocean. J. Phys. Oceanogr., 35, 255-267, doi: 10.1175/JPO2682.1. [Link]

Quadfasel, D. and G. R. Cresswell, 1992: A note on the seasonal variability of the South Java Current. J. Geophys. Res., 97, 3685-3688, doi: 10.1029/91JC03056. [Link]

Ralph, A. E. and P. P. Niiler, 1999: Wind-driven currents in the tropical Pacific. J. Phys. Oceanogr., 29, 21212129, doi: 10.1175/1520-0485(1999)029<2121:WDCI TT>2.0.CO;2. [Link]

Reason, C. J. C., J. R. E. Lutjeharms, J. Hermes, A. Biastoch, and R. E. Roman, 2003: Inter-ocean fluxes south of Africa in an eddy-permitting model. Deep-Sea Res. Part II-Top. Stud. Oceanogr., 50, 281-298, doi: 10.1016/S0967-0645(02)00385-5. [Link] 
Reid, J. L., 2003: On the total geostrophic circulation of the Indian Ocean: Flow patterns, tracers, and transports. Prog. Oceanogr., 56, 137-186, doi: 10.1016/S00796611(02)00141-6. [Link]

Reverdin, G., M. Fieux, J. Gonella and J. Luyten, 1983: Free drifting buoy measurements in the Indian Ocean equatorial jet. In: Nihoul, J. C. J. (Ed.), Hydrodynamics of the Equatorial Ocean, Elsevier Oceanography Series, Elsevier, New York, 99-120.

Ridderinkhof, H. and W. P. M. de Ruijter, 2003: Moored current observations in the Mozambique Channel. DeepSea Res. Part II-Top. Stud. Oceanogr., 50, 1933-1955, doi: 10.1016/S0967-0645(03)00041-9. [Link]

Rio, M. H. and F. Hernandez, 2004: A mean dynamic topography computed over the world ocean from altimetry, in situ measurements, and a geoid model. J. Geophys. Res., 109, C12032, doi: 10.1029/2003JC002226. [Link]

Rio, M. H., S. Guinehut, and G. Larnicol, 2011: New CNESCLS09 global mean dynamic topography computed from the combination of GRACE data, altimetry, and in situ measurements. J. Geophys. Res., 116, C07018, doi: 10.1029/2010JC006505. [Link]

Roshin, P. R., N. P. Benny, and P. Dhanya, 2010: Oceanic and atmospheric influences on the variability of phytoplankton bloom in the Southwestern Indian Ocean. J. Mar. Syst., 82, 217-229, doi: 10.1016/j.jmarsys.2010.05.009. [Link]

Schott, F. A. and J. P. McCreary Jr., 2001: The monsoon circulation of the Indian Ocean. Prog. Oceanogr., 51, 1-123, doi: 10.1016/S0079-6611(01)00083-0. [Link]

Schouten, M. W., W. P. M de Ruijter, and P. J. van Leeuwen, 2002: Upstream control of Agulhas Ring shedding. J. Geophys. Res., 107, 23-1-23-11, doi: 10.1029/ 2001JC000804. [Link]

Shetye, S. R. and G. S. Michael, 1988: Satellite-tracked drifting buoy observations in the south equatorial current in the Indian Ocean. Proc. Indian Acad. Sci. Earth Planet. Sci., 97, 149-157, doi: 10.1007/BF02861850. [Link]

Shenoi, S. S. C., P. K. Saji, and A. M. Almeida, 1999: Nearsurface circulation and kinetic energy in the tropical Indian Ocean derived from Lagrangian drifters. J. Mar. Res., 57, 885-907, doi: 10.1357/002224099321514088. [Link]

Stramma, L. and J. R. E. Lutjeharms, 1997: The flow field of the subtropical gyre of the South Indian Ocean. J. Geophys. Res., 102, 5513-5530, doi: 10.1029/96JC03455. [Link]

Sudre, J. and R. A. Morrow, 2008: Global surface currents: A high-resolution product for investigating ocean dynamics. Ocean Dyn., 58, 101-118, doi: 10.1007/ s10236-008-0134-9. [Link]

Thompson, K. R. and E. Demirov, 2006: Skewness of sea level variability of the world's oceans. J. Geophys. Res., 111, C05005, doi: 10.1029/2004JC002839. [Link]

Uchida, H. and S. Imawaki, 2003: Eulerian mean surface velocity field derived by combining drifter and satellite altimeter data. Geophys. Res. Lett., 30, doi: 10.1029/2002GL016445. [Link]

Wijffels, S. and G. Meyers, 2004: An intersection of oceanic waveguides: Variability in the Indonesian throughflow region. J. Phys. Oceanogr., 34, 1232-1253, doi: 10.1 175/1520-0485(2004)034<1232:AIOOWV>2.0.CO;2. [Link]

Woodberry, K. E., M. E. Luther, and J. J. O’Brien, 1989: The wind-driven seasonal circulation in the southern tropical Indian Ocean. J. Geophys. Res., 94, 1798518002, doi: 10.1029/JC094iC12p17985. [Link]

Wyrtki, K., 1971: Oceanographic Atlas of the International Indian Ocean Expedition, National Science Foundation, Washington, 531 pp. 